\title{
POTENSI EKONOMI PARIWISATA KABUPATEN PULAU MOROTAI
}

\section{Economic Potential of Tourism at the Morotai Island Regency}

\author{
*Cornelia Miwantini Witomo dan Andrian Ramadhan \\ Balai Besar Riset Sosial Ekonomi Kelautan dan Perikanan \\ Gedung Balitbang KP I Lt. 4 \\ Jalan Pasir Putih Nomor 1 Ancol Timur, Jakarta Utara, Indonesia \\ Telp: (021) 64711583 Fax: 64700924 \\ Diterima tanggal: 14 April 2018 Diterima setelah perbaikan: 21 Mei 2018 \\ Disetujui terbit: 18 Juni 2018 \\ *email: tone_poenya@yahoo.com
}

\begin{abstract}
ABSTRAK
Tujuan dari penelitian ini adalah untuk menghitung potensi ekonomi pariwisata Kabupaten Pulau Morotai. Kabupaten Pulau Morotai sebagai Kawasan Ekonomi Khusus (KEK) Pariwisata Bahari menjadikan pariwisata sebagai salah satu sumber pemasukan daerah karena atraksi wisata yang ada berdasarkan potensi sumber daya alam dan peninggalan sejarah. Pendekatan yang digunakan dalam penelitian ini adalah penelitian kualitatif metode deskritif dan desk study. Analisis data yang digunakan dalam penelitian ini adalah analisis benefit transfer dari hasil penelitian sebelumnya di Kabupaten Pulau Morotai yang menggunakan metode travel cost method (TCM). Berdasarkan hasil wawancara dan observasi, daya tarik wisata di Kabupaten Pulau Morotai adalah wisata alam seperti wisata alam bawah laut, wisata pantai serta wisata budaya dari hasil peninggalan sejarah diantaranya peninggalan sejarah Perang Dunia II. Berdasarkan hasil perhitungan daya tarik wisata di Kabupaten Pulau Morotai potensi ekonomi Pariwisata Kabupaten Pulau Morotai adalah Rp13.295.140.000. Nilai ini disumbang dari wisatawan domestik dan wisatawan mancanegara yang berkunjung ke Kabupaten Pulau Morotai selama 4 -11 hari. Memasukan potensi ekonomi dalam dokumen perencanaan pengembangan pariwisata Kabupaten Pulau Morotai merupakan salah satu dasar dasar untuk membuka pintu investasi baik untuk menanamkan modal dalam pengembangan pariwisata.
\end{abstract}

Kata Kunci: pariwisata; bahari; ekonomi; Morotai

\begin{abstract}
This research aims to calculate economic potential of tourism at Morotai Island Regency. Regency of Morotai has tourist attraction due to its natural resources and historical heritage. It is branded as Special Economic Zone (KEK) of Marine Tourism and make tourism as one of the source of its regional income. This research used descriptive qualitative and desk study method. The data is analyzed using benefit transfer analysis from the previous research which uses travel cost method (TCM). Based on interview and observation, marine tourism such as underwater travel, beach and cultural attraction, is a leading tourist attraction at Morotai Island Regency. Tourist attraction calculates the number of economic potential of tourism at Regency of Morotai Island amount IDR 13.295.140.000. It is contributed mostly from domestic and foreign travelers who traveled to Morotai Island for 4 to 11 days. Therefore, economic potential of tourism will lead to investment in tourism development.
\end{abstract}

Keywords: tourism; maritime; economics; Morotai

\section{PENDAHULUAN}

Pariwisata mulai ada sejak terjadinya perpindahan manusia baik karena dorongan untuk melakukan perdagangan, perasaan ingin tahu atau mencari pengalaman baru dan ilmu pengetahuan baru serta dorongan keagamaan atau melakukan ziarah (Spillane, 1987). Pariwisata saat ini dijadikan sebagai sumber pendapatan valuta asing, penyerapan tenaga kerja lokal dan sumber pertumbuhan ekonomi negara (Brida et al., 2010a). Pariwisata tercatat telah berkontribusi $4 \%$ dari total perekonomian (www.indonesia-investment. com, 2016) dan tahun 2015 sudah menyumbang devisa sebesar 12 juta USD urutan ke 4 dari 11 ekspor barang terbesar Indonesia. Jumlah kunjungan wistawan mancanegara dari 19 pintu 
masuk utama dan pintu masuk lainnya tercatat mengalami peningkatan $21,88 \%$ dari tahun 2016 ke tahun 2017 yang mencapai lebih dari 14 juta orang (Ditjen Imigrasi dan BPS, 2017). Hal ini didorong karena semakin banyaknya destinasi wisata di Indonesia dan acara festival yang banyak diselenggarakan setiap bulannya di berbagai wilayah di Indonesia serta diikuti dengan perkembangan positif investasi di sektor pariwisata. Pertumbuhan sektor pariwisata juga disebabkan oleh banyaknya wisatawan di tingkat internasional walaupun beberapa negara dunia mengalami krisis global, dimana jumlah wisatawan yang melakukan kunjungan tahun 2015 sebanyak 1,18 milyar orang (Khumaedy, 2017).

Perkembangan kunjungan wisatawan akan berbanding lurus dengan pertumbuhan sektor pariwisata kearah positif. Secara tidak langsung pertumbuhan positif ini memberikan efek berganda pada permintaan terhadap produk yang mendukung sektor pariwisata. Semakin tinggi permintaan terhadap sektor pariwisata tidak menutup kemungkinan sektor lainnya akan ikut tumbuh secara positif (Purwanto, 2013). Salah satu destinasi wisata yang memiliki atraksi menarik dan berbeda dengan destinasi wisata bahari lainnya adalah Kabupaten Pulau Morotai. Kabupaten Pulau Morotai sebagai salah satu wilayah pulau terluar bagian utara menghadap kepada Samudera Pasifik memiliki keunggulan geopolitik dan ekonomi serta memiliki potensi sumber daya bahari yang kaya akan alam bawah lautnya juga memiliki daya tarik wisata budaya sejarah yaitu peninggalan perang dunia II. Kabupaten Pulau Morotai dijadikan sebagai salah satu lokasi Kawasan Ekonomi Khusus (KEK) Pariwisata yang ditetapkan pada saat Sail Morotai 2012 oleh Presiden Susilo Bambang Yudhoyono. Penetapan suatu kawasan menjadi kawasan khusus adalah untuk pengembangan kawasan tersebut sebagai kawasan pembangunan ekonomi yang nantinya akan memberikan ruang kepada perusahaanperusahanan untuk berinvestasi tanpa harus melalui birokrasi yang rumit. Dengan kata lainnya dengan masuknya investor untuk mengairahkan ekonomi di kawasan tersebut nantinya akan diikuti pertumbuhan ekonomi di wilayah sekitarnya.

Penetapan KEK di Kabupaten Pulau Morotai diharapkan membawa dampak positif terhadap peningkatan pendapatan masyarakat, peningkatan lapangan kerja, peningkatan pajak baik langsung dan tidak langsung. Namun ketika ada pembangunan pariwisata di suatu kawasan akan memberikan tekanan terhadap sumber daya alam karena sumber daya alam memberikan manfaat ekonomi dari barang dan jasa yang digunakan sebagai atraksi wisata. Perhitungan besarnya manfaat ekonomi sumber daya alam untuk sektor pariwisata sebagai daya tarik wisata Kabupaten Pulau Morotai. Di lain pihak melakukan perhitungan terhadap potensi ekonomi pariwisata sebagai bentuk mengukur nilai lingkungan yang terdapat pada destinasi wisata. Potensi ekonomi pariwisata muncul ketika ada barang dan jasa lingkungan yang dimanfaatkan khususnya untuk kegiatan pariwisata dan adanya transaksi ekonomi didalamnya. Menurut Zamroni et al. (2016) nilai lingkungan akan menurun seiring dengan rusaknya lingkungan karena barang dan jasa yang dihasilkan dari lingkungan menurun. Perhitungan nilai ekonomi terhadap sumber daya alam berdasarkan karakteristik pemanfaatan kegiatan pariwisata penting untuk dilakukan sebagai dasar mengimplemetasikan program kerja yang terukur secara ekonomi untuk perbaikan lingkungan dan menyeimbangkan pertumbuhan ekonomi dengan keberlanjutan sumber daya alam (Letson, 2002). Berdasarkan hal tersebut tujuan dari penelitian ini adalah untuk menghitung potensi ekonomi pariwisata Kabupaten Pulau Morotai berdasarkan aktraksi wisata yang ada dan nilai ekonomi sehingga dapat digunakan dalam Masterplan KEK Pariwisata untuk pembangunan dan pengembangan pariwisata berkelanjutan di Kabupaten Pulau Morotai.

\section{METODOLOGI}

\section{Waktu dan Lokasi Penelitian}

Penelitian dilakukan pada tahun 2017 di Kabupaten Pulau Morotai. Kabupaten Pulau Morotai sebagai salah satu lokasi KEK (Kawasan Ekonomi Khusus) yang bergerak di bidang pariwisata. Pemilihan lokasi penelitian berdasarkan pertimbangan potensi yang ada di Kabupaten Pulau Morotai seperti peninggalan sejarah Perang Dunia II dan potensi sumber daya kelautan perikanan yang ditetapkan melalui Peraturan Pemerintah No. 50 Tahun 2014. Selain sebagai lokasi KEK, Kabupaten Pulau Morotai ditetapkan sebagai salah satu lokasi Sentra Kelautan dan Perikanan Terpadu atau SKPT dari enam lokasi SKPT yang ditetapkan oleh Kementerian Kelautan Perikanan yang diharapkan dapat menjadi leading sector percepatan pembangunan industri 
perikanan nasional sebagai salah satu upaya pelaksanaan pilar poros maritim sesuai dengan Instruksi Presiden No. 7 Tahun 2016. SKPT dibangun dengan tujuan untuk mengintegrasikan proses bisnis kelautan dan perikanan berbasis masyarakat melalui optimalisasi pemanfaatan sumber daya kelautan dan perikanan di pulaupulau kecil dan/atau kawasan perbatasan secara berkelanjutan.

\section{Jenis dan Sumber Data}

Pendekatan penelitian yang digunakan adalah kombinasi penelitian kuantitatif kualitatif. Penelitian kuantitatif dan kualitatif banyak dilakukan pada penelitian sosial jika hanya melakukan pendekatan kuantitatif tidak akan bermakna jika tidak diperkaya dengan pendekatan kualitatif dan sebaliknya jika hanya pendekatan kualitatif tanpa adanya pendekatan kuantitatif data yang disajikan dalam bentuk kalimat mudah untuk direkayasa (Mulyadi, 2011). Penelitian ini dilakukan dengan cara mengumpulkan data yang berupa angka dan kalimat dari individu serta literatur termasuk hasil-hasil penelitian sejenis yang sudah dilakukan sebelumnya (Martono, 2011)

Pendekatan perhitungan potensi ekonomi diukur dari dampak ekonomi secara langsung.
Dampak langsung berasal dari nilai tranksasi yang nyata digunakan oleh wisatawan di daerah tujuan wisata (Marpaung dan Bahar, 2002). Jenis data yang digunakan adalah data primer dan data sekunder. Data primer adalah data yang secara langsung diperoleh dengan cara wawancara kepada informan kunci yaitu pengelola Daloha Resort dan operator jasa penyedia pariwisata yang ada di Daloha Resort. Daloha Resort sebagai basis operator PT Jababeka Morotai sebagai pengelola Kawasan Ekonomi Khusus (KEK) Morotai. Data primer yang diperoleh memuat informasi terkait dengan paket wisata, asal wisatawan, jumlah hari menginap, aktraksi wisata.

Data sekunder yang dimaksud adalah data-data yang diperoleh dari hasil penelitian terdahulu yang terkait dengan penelitian ini. Data sekunder yang dimaksud adalah potensi ekonomi pariwisata Kabupaten Pulau Morotai dari perhitungan Travel Cost Method (TCM) dan Willingness to Pay (WTP) yang penelitiannya dilakukan pada tahun 2006 - 2007. Data sekunder lainnya adalah rata-rata jumlah hari wisatawan berlibur baik wisatawan domestik dan wisatawan mancanegara, jumlah kunjungan wisatawan ke Kabupaten Pulau Morotai, biaya perjalanan wisatawan (Tabel 1).

Tabel 1. Jenis dan Sumber Data Sekunder Penelitian Potensi Ekonomi Pariwisata di Kabupaten Pulau Morotai 2017.

Table 1. Type of Data and Source of Secondary Data For Economics Tourism Potency in Morotai Island Regency, 2017.

\begin{tabular}{|c|c|c|c|c|}
\hline No & $\begin{array}{l}\text { Data dan Informas/ } \\
\text { Information and Data }\end{array}$ & $\begin{array}{l}\text { Sumberl } \\
\text { Source }\end{array}$ & $\begin{array}{l}\text { Tahun/ } \\
\text { Year }\end{array}$ & $\begin{array}{l}\text { Keterangan/ } \\
\text { Remaks }\end{array}$ \\
\hline 1. & $\begin{array}{l}\text { Potensi Ekonomi } \\
\text { Pariwisata Kabupaten } \\
\text { Pulau Morotai/ Potential } \\
\text { Economics Tourism of } \\
\text { Morotai Island Regency }\end{array}$ & Banapon & 2008 & 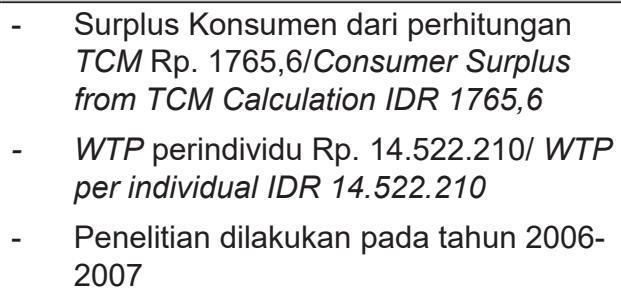 \\
\hline 2. & $\begin{array}{l}\text { Rata-rata Hari } \\
\text { Berkunjung/Average } \\
\text { days of visiting }\end{array}$ & $\begin{array}{l}\text { BPS (Diolah } \\
\text { Kembali-2017)/ BPS } \\
\text { (Update Primary Data } \\
\text { Processed 2017) }\end{array}$ & 2016 & $\begin{array}{l}\text { - Wisatawan Domestik } 4 \text { hari } 3 \text { malam/ } \\
\text { Domestic Tourist } 4 \text { days } 3 \text { nights } \\
\text { - Wisatawan Mancanegara } 11 \text { hari } 10 \\
\text { malam/Foreign Tourist } 11 \text { days } 10 \\
\text { nights }\end{array}$ \\
\hline 3. & $\begin{array}{l}\text { Pengeluaran Perhari/ } \\
\text { Daily Expenditure }\end{array}$ & $\begin{array}{l}\text { Kementerian Pariwisata } \\
\text { (Diolah Kembali-2017)/ } \\
\text { Ministry of Tourism } \\
\text { (Update Primary Data } \\
\text { Processed 2017) }\end{array}$ & 2014 & $\begin{array}{l}\text { - Wisatawan Asia dan Timur Tengah } \\
\text { USD 136/Tourist from Asia and Middle } \\
\text { East USD } 136 \\
\text { - Wisatawan Eropa dan Amerika USD } \\
\text { 111/Tourist from Europe and US USD } \\
111\end{array}$ \\
\hline
\end{tabular}




\section{Metode Pengumpulan Data}

Metode yang digunakan dalam pengumpulan data adalah wawancara mendalam dan studi kepustakaan. Pengumpulan data dengan cara wawancara mendalam kepada pengelola KEK Morotai yaitu PT Jababeka Morotai. Selain melakukan wawancara mendalam juga melakukan observasi non partisipan secara langsung terhadap perkembangan pariwisata di Kabupaten Pulau Morotai. Obsevasi non partisipan tidak terlibat langsung dengan kehidupan masyarakat namun hanya sebagai pengamat (Martono, 2011). Metode pengumpulan data lainnya adalah studi pustaka. Menurut Wirartha (2006), metode studi pustaka adalah penelitian kepustakaan yang digunakan oleh peneliti untuk menganalisis data yang diperoleh dari dokumen literatur melalui berbagai sumber kepustakaan. Data dan informasi pendukung serta hasil penelitian yang telah dilakukan oleh berbagai pihak terutama yang berhubungan dengan kegiatan kajian. Sumber data yang digunakan bersifat selektif dan memuat prinsip relevansi dan kemuktahiran (Harahap, 2014). Kemuktahiran dilihat tidak terbatas pada tahun tertentu karena bisa saja penelitian yang serupa di lokasi tertentu belum ada yang dipublikasi pada tahun terbaru

\section{Metode Analisis Data}

Metode analisis data yang digunakan dalam penelitian ini adalah analisis data sekunder. Analisis data sekunder memanfaatkan data yang tersedia dari lembaga pemerintah atau sumber terpercaya lainnya yang relevan dengan penelitian ini (Sugiyono, 2013). Setelah data berupa angka dikumpulkan dan maka selanjutnya dilakukan discounting. Menurut Fauzi (2014) discounting adalah prosedur ekonomi yang dilakukan dengan cara transformasi aliran uang yang terjadi antar waktu ataupun pada waktu tertentu pada suatu nilai tertentu yang setara waktu sekarang atau secara umum adalah menentukan nilai waktu sekarang dari manfaat dan biaya akan terjadi di masa mendatang melalui pembobotan yang disebut discount factor. Besaran discount rate/suku bunga pasar ( $r$ ) yang digunakan dalam penelitian ini adalah $6,15 \%$ dengan asumsi elastisitas utilitas sama dengan 1 , suku bunga preferensi waktu murni sama dengan 1 dan laju pertumbuhan konsumsi Indonesia tahun 2014 tercatat 5,15\%. Discount rate diperoleh dari formula Ramsey (Fauzi, 2014). Formula Ramsey dalam menghitung discount rate adalah sebagai berikut:

$$
r=\eta g+\rho
$$

Keterangan/Remaks

$r=$ Suku bunga pasar/Discount rate

$\eta=$ Elastisitas utilitas marjinal/Elasticity of marginal utility

$g=$ Laju pertumbuhan konsumsi/ Consumption growth

$\rho=$ Suku bunga preferensi waktu murni/ Interest rate of time preference

Formula dalam menghitung discount factor adalah:

$$
d f=\frac{1}{(1+r)}
$$

\section{Keterangan/Remaks}

$d f=$ Diskon faktor/Discount factor

$r$ = Suku bunga pasar/Discount rate

Dasar pemilihan waktu untuk menghitung potensi ekonomi pariwisata berdasarkan data yang tersedia. Data yang dimaksud adalah jumlah wisatawan yang berkunjung ke Kabupaten Pulau Morotai tercatat pada tahun 2014. Oleh karena itu perhitungan discounting merujuk pada tahun 2014 dengan menggunakan discount rate yang telah dihitung sebelumnya.

Analisis yang dilakukan menggunakan statistik deskriptif yang digunakan untuk menganalisis data dengan cara mendeskripsikan data yang telah terkumpul dan dianalisis dengan sederhana menggunakan discounting tanpa maksud membuat kesimpulan yang berlaku secara umum (Sugiyono, 2013). Secara umum hasil dari analisis deskriptif adalah potensi ekonomi pariwisata yang terhitung dari data yang dikumpulkan sebagai dasar pengembangan ekonomi sektor pariwisata di Kabupaten Pulau Morotai.

Selain analisis data yang sudah disebutkan sebelumnya, penelitian ini menggunakan hasil penelitian Banapon (2008) berupa surplus konsumen wisatawan yang diperoleh dari metode travel cost method (TCM). Tujuan dasar dari TCM adalah ingin mengetahui nilai manfaat dari sumberdaya alam dengan proxy atau secara sederhana dengan mengetahui biaya yang dikeluarkan untuk mengkonsumsi jasa dari sumberdaya alam tersebut dapat digunakan sebagai pendekatan untuk menentukkan harga 
dari sumberdaya alam (Fauzi, 2004). Dengan mengetahui biaya perjalanan dari lokasi asal wisatawan menuju lokasi tujuan wisata dapat ditulis dalam persamaan berikut:

$$
X=f(c, d, I, u, P)
$$

\section{Keterangan/Remaks}

$\begin{array}{lll}X & = & \text { Jumlah kunjungan/Total visit } \\ \mathrm{C} & = & \text { Biaya perjalanan/Trave/ cost } \\ \mathrm{d} & = & \text { Jarak/Distance } \\ \mathrm{i} & = & \text { Pendapatan/Income } \\ \mathrm{u} & = & \text { Umur/Age } \\ \mathrm{P} & = & \text { Harga barang substitusi/ } \\ & \text { Substitute goods price }\end{array}$

$$
\ln V_{t}=\beta_{o}+\beta_{1} \ln T C_{1}+\beta_{2} \ln I N C_{1}
$$

$$
\begin{aligned}
& \text { Keterangan/Remaks } \\
& \begin{array}{ll}
\mathrm{Vt} & =\text { Tingkat kunjungan/Visit level } \\
\mathrm{TC}_{\mathrm{i}} & \text { Biaya perjalanan/Travel cost } \\
\mathrm{INC}_{\mathrm{i}}= & \text { Pendapatan individu/Income individu } \\
\beta_{0} \beta_{1} \beta_{2}= & \text { Koefisien regresi } / \\
& \text { Regression coefficient }
\end{array}
\end{aligned}
$$

\begin{tabular}{|c|c|c|}
\hline TCS & $=$ & $\begin{array}{l}\text { Total surplus konsumen/nilai ekonomi } \\
\text { pariwisata/Consumer surplus total or } \\
\text { tourism value }\end{array}$ \\
\hline $\mathrm{CS}_{\mathrm{i}}$ & - & Surplus konsumen/Consumer surplus \\
\hline$V_{1}$ & $=$ & $\begin{array}{l}\text { Total kunjungan pada tahun analisis } \\
\text { (tahun ke-t)/Number of visitor in the } \\
\text { year of analysis }\end{array}$ \\
\hline
\end{tabular}

$$
C S_{i}=\frac{-V_{i}}{\beta_{i}}
$$

\section{Keterangan/Remaks}

$$
\begin{array}{ll}
C S_{i}= & \begin{array}{l}
\text { Surplus konsumen individu/Individual } \\
\text { consumer surplus }
\end{array} \\
\mathrm{V}_{\mathrm{i}} \quad= & \begin{array}{l}
\text { Tingkat kunjungan individu/Individual } \\
\text { visit level }
\end{array} \\
\beta_{1} \quad= & \begin{array}{l}
\text { Koefisien regresi untuk biaya } \\
\text { perjalanan/Regression coefficient for } \\
\text { travel cost }
\end{array}
\end{array}
$$

$$
T C S=C S_{I}+V_{t}
$$

\section{Keterangan/Remaks}

Metode lain yang digunakan oleh Banapon (2008) adalah metode kontingensi/contingen value method (CVM). Nilai ekonomi yang diperoleh dari CVM dijumlahkan dengan nilai ekonomi yang diperoleh dari TCM menjadi total nilai ekonomi pariwisata di Kabupaten Pulau Morotai. CVM digunakan untuk menghitung nilai ameniti atau estetika lingkungan dari suatu barang publik. Barang publik adalah barang yang dapat dinikmati oleh seseorang tanpa harus mengurangi manfaat barang tersebut untuk dinikmati oleh orang lain. Nilai estetika lingkungan dapat didapatkan dengan cara wawancara kepada responden namun harus hati-hati karena nilai dari responden mewakili populasi sehingga nilai tersebut dapat merepresentasikan nilai yang sebenarnya.

Pemberian nilai ekonomi terhadap sumber daya alam dapat didekatkan dengan cara kemampuan individu untuk mengeluarkan sejumlah uang untuk menjaga estetika sumber daya alam tersebut atau dengan kata lain besaran keinginan untuk membayar atau Willingness to Pay (WTP). Estimasi WTP yang bangun dalam penelitian Banapon (2008) adalah menduga hubungan antara WTP dengan karakteristik responden yang menggambarkan nilai penghargaan yang diberikan oleh individu yang selalu memanfaatkan sumber daya alam tersebut. Estimasi nilai WTP dapat dinilai dari fungsi berikut:

$W T P_{i}=\beta_{o}+\beta_{1} X_{1}+\beta_{2} X_{2}+\beta_{3} X_{3}$

\section{Keterangan/Remaks}

$$
\begin{aligned}
\text { WTP }_{\mathrm{i}} & =\text { Kemampuan responden membayar/ } \\
& \text { Willingness to pay } \\
\mathrm{X}_{1} & \text { Umur responden/Age of respondent } \\
\mathrm{X}_{2} & \text { Pendapatan responden/Income of } \\
& \text { respondent } \\
\mathrm{X}_{3} & \text { Pendidikan responden/Education } \\
& \text { level of respondent } \\
\beta_{0} \beta_{1} \beta_{2} \beta_{3}= & \text { Koefisien regresi/Regression } \\
& \text { coefficient }
\end{aligned}
$$

Analisis selanjutnya menghitung total manfaat yang diperoleh dari nilai WTP individu yang dihasilkan dari persamaan sebelumnya dikalikan dengan total populasi. Secara sederhana tertuang dalam persamaan berikut:

$$
T M=W T P_{i} x P_{t}
$$


Keterangan/Remaks

$\begin{array}{ll}\mathrm{TM}= & \text { Total manfaat } / \text { Total benefit } \\ \mathrm{WTPi}= & \text { Nilai WTP per individu/ Individual } \\ & \text { WTP value } \\ \mathrm{Pt}= & \begin{array}{l}\text { Total populasi pada tahun ke-t yang } \\ \text { relevan dengan analisis/ Number of } \\ \text { population in the year of analysis }\end{array}\end{array}$

Menurut Banapon (2008) total manfaat ini dapat dilakukan untuk penelitian multi years dengan cara mendiskon sesuai dengan prosedur yang berlaku dengan menggunakan tingkat diskon yang sesuai dengan karakteristik sumberdaya alam yang akan dihitung.

\section{HASIL DAN PEMBAHASAN}

\section{Atraksi Wisata Kabupaten Pulau Morotai}

Daya tarik wisata di Kabupaten Pulau Morotai adalah wisata alam seperti wisata alam bawah laut, wisata pantai serta wisata budaya dari hasil peninggalan sejarah seperti peninggalan sejarah Perang Dunia II. Aktivitas wisata yang bisa dinikmati oleh para wisatawan di Pulau Morotai antara lain rekreasi pantai, snorkeling, diving, (terutama di situs bangkai kapal perang dunia II), sun bathing, serta wisata sejarah yang menjadi andalan utama kekhasan lainnya adalah wisata budaya yang unik dan khas budaya timur dan ada anggapan bahwa wisatawan asing senang dengan destinasi yang memberikan atraksi budaya karena menurut wisatawan sangat eksotik dan layak untuk dikunjungi dan dinikmati (Spillane, 1987).

Berdasarkan hasil wawancara destinasi utama para wisatawan yang ada di Kabupaten Pulau Morotai adalah Pulau Dodola. Pulau Dodola terletak di bagian barat Pulau Besar Morotai yang dapat dijangkau dengan menggunakan speed boat dari Daruba selama kurang lebih 20 menit. Pulau lainnya yang menjadi objek wisata alam adalah Pulau Zum Zum. Pulau ini sangat istimewa karena pemimpin pasukan sekutu untuk kawasan Asia Pasifik masa Perang Dunia II Jenderal Douglas Mac Arthur pernah tinggal disini. Objek wisata alam lainnya yang tidak kalah menarik adalah Tanjung Gorango dan Tanjung Sopi. Tanjung Gorango yang terletak Desa Gorua dan Korango Kecamatan Morotai Utara sedangkan Tanjung Sopi yang terletak di Desa Sopi. Tanjung Gorango terkenal dengan panorama pasir putih sedangkan Tanjung Sopi terkenal dengan ombak besar karena langsung berhadapan dengan Samudera Pasifik sehingga ini adalah titik untuk berselancar.
Destinasi objek wisata alam yang tidak kalah menarik adalah Air Kaca. Air Kaca adalah tempat pemandian Jenderal Douglas Mac Arthur disebut Air Kaca karena airnya yang jernih dan sebening kaca. Objek wisata alam Kabupaten Pulau Morotai tidak hanya ada di darat namun juga di bawah laut. Untuk melihat alam bawah laut di Kabupaten Pulau Morotai titik menyelam terdapat 28 titik yang tersebar di perairan Morotai. Titik penyelaman di Kabupaten Pulau Morotai meliputi shark dive dan wreck dive. Shark dive adalah lokasi penyelaman dengan target untuk melihat ikan hiu yang hidup di perairan Morotai sedangkan wreck dive adalah lokasi penyelaman selain melihat terumbu karang adalah melihat peninggalan Perang Dunia II berupa bangkai pesawat.

Selain objek wisata alam, atraksi wisata yang ditawarkan adalah objek wisata sejarah. Berdasarkan hasil wawancara, Pulau Zum-Zum dan Air Kaca tidak hanya memiliki nilai keindahan tetapi juga memiliki nilai sejarah karena Jenderal Douglas Mac Arthur pernah menetap dan hidup di tempat itu. Objek wisata sejarah lainnya adalah Landasan Pitoe yang merupakan landasan udara yang digunakan pada saat Perang Dunia II yang berjumlah tujuh landasan hal ini yang menyebabkan landasan ini dinamakan Landasan Pitoe. Pada saat Perang Dunia II Jenderal Douglas Mac Arthur mendarat bersama pesawat sekutu di Kabupaten Pulau Morotai dan menjadikan basis militer karena letaknya yang strategis dekat dengan Filipina dan pintu masuk ke Samudera Pasifik. Objek wisata sejarah yang berhubungan dengan bangsa Indonesia adalah museum Trikora sebagai peringatan perintah Soekarno dalam rangka pembebasan Irian Barat dibawah jajahan Belanda dan menjadikan Kabupaten Pulau Morotai sebagai pangkalan terluar tentara Indonesia untuk menyerang Belanda di Irian Barat.

Negara Jepang sangat tertarik dengan keberadaan Kabupaten Pulau Morotai karena dari segi sejarah banyak tentara Jepang yang gugur dalam perang dan dimakamkan secara massal di Kabupaten Pulau Morotai. Salah satu bukti sejarah tentara Jepang pernah ada di Kabupaten Pulau Morotai adalah adanya Gua Nakamura yang merupakan gua persembunyian seeorang tentara Jepang bernama Teruo Nakamura yang bersembunyi dari tentara sekutu di hutan pegunungan Galoka karena menolak menyerahkan diri kepada tentara sekutu. Pada tahun 1974 atau 30 tahun kemudian Teruo Nakamura ditemukan 
oleh tim TNI AU atas permintaan pemerintahan bantuan Jepang. Salah satu bukti Kabupaten Pulau Morotai menjadi basis militer pada Perang Dunia II banyak ditemukan barang-barang peninggalan Perang Dunia II seperti senjata, peluru, koin, sendok, garpu, kalung.

Berdasarkan BPS Kabupaten Pulau Morotai (2018), PDRB tahun 2013-2017 atas dasar harga konstan 2010 kontribusi pariwisata yang tercermin dari lapangan usaha penyediaan akomodasi dan makan minum pertumbuhannya bergerak lambat yaitu sebesar $29 \%$. Berdasarkan hasil wawancara dan observasi hal ini dapat disebabkan salah satunya penawaran pariwisata Kabupaten Pulau Morotai yang memuat aspek ketersediaan dan keterjangkauan tergolong rendah. Salah satu contohnya adalah ketersediaan prasarana dan sarana serta infrastruktur pariwisata seperti hotel, restoran, pusat oleh-oleh dan keterjangkauan yang kurang mudah namun saat ini sudah mengalami perubahan yang ke arah yang cukup baik seperti pembukaan jalur udara dari ternate-morotai-ternate namun hanya 1 kali penerbangan dalam sehari (pulang-pergi).

Kabupaten Pulau Morotai merupakan salah satu kawasan pulau-pulau kecil yang memiliki potensi ekonomi tinggi dikembangkan sebagai kawasan ekonomi khusus bidang pariwisata. Selain memiliki nilai sejarah yang tinggi, kawasan ini juga memiliki kekayaan biota laut yang beraneka ragam. Namun sejauh ini belum termanfaatkan secara optimal untuk peningkatan kesejahteraan masyarakat disekitarnya. Berdasarkan observasi secara langsung belum terlihat pergerakan ekonomi di bidang pariwisata walaupun sudah ditetapkan sebagai wilayah KEK seperti jumlah kunjungan yang tidak signifikan meningkat kecuali pada saat acara Sail Morotai. Selain itu kurangnya akses pada destinasi tertentu sehingga membutuhkan waktu dikarenakan kondisi jalan yang kurang memadai dan pembangunan infrastrukur pariwisata yang belum sesuai target seperti pembebasan lahan oleh PT Jababeka Morotai masih tersisa 50\% dari target hingga akhir dari kontrak yang disepakati.

Menurut Bappeda Kabupaten Pulau Morotai (2015a), Perwujudan Kawasan Peruntukan Pariwisata meliputi penataan dan optimalisasi fungsi objek wisata, pengembangan infrastruktur pendukung, peningkatan aksesbilitas menuju obyek wisata, peningkatan pemasaran dan promosi potensi wisata daerah, dan penyadaran publik dibidang kepariwisataan. Namun ada ketentuan umum peraturan zonasi untuk kawasan peruntukan pariwisata. Ketentuan tersebut meliputi (a) pengembangan kawasan pariwisata harus tetap memperhatikan kelestarian ekosistem lingkungan; (b) pengembangan kawasan pariwisata harus tetap memperhatikan kelestarian fungsi lindung; (c) peningkatan kualitas pariwisata agar terwujud "pariwisata berkualitas"; (d) pengembangan kawasan pariwisata didukung oleh pengembangan kawasan penunjang pariwisata serta obyek dan daya tarik wisata; (e) pengembangan obyek dan daya tarik wisata dengan tetap memperhatikan fungsi konservasi kawasan; (f) pengembangan kawasan agrowisata untuk memberikan keberagaman obyek wisata di daerah, dengan fasilitas pendukung dan akomodasi seluasluasnya $2,5 \%$ dari total pengelolaan lahan ekowisata; (g) optimalisasi pemanfaatan lahanlahan tidur yang sementara tidak diusahakan; (h) perlindungan terhadap situs peninggalan kebudayaan masa lampau; (i) diizinkan pengembangan aktivitas komersial sesuai dengan skala daya tarik pariwisatanyan; (j) diizinkan secara terbatas pengembangan aktivitas perumahan dan permukiman dengan syarat di luar zona utama pariwisata dan tidak mengganggu bentang alam daya tarik pariwisata; (k) pembatasan pendirian bangunan hanya untuk menunjang pariwisata; dan (I) mengendalikan pertumbuhan sarana dan prasarana pariwisata.

Wilayah Pengembangan I meliputi Kecamatan Morotai Selatan, Morotai Selatan Barat dan Morotai Timur yang diperuntukan sebagai pusat pengembangan pariwisata dan pengembangan industri berbasis perikanan. Pariwisata yang akan dikembangkan berupa marine ecotourism yang akan dikembangkan di kawasan Daruba dan pulau-pulau kecil di sekitarnya seperti Pulau Dodola dan sebagainya. Sementara pengembangan kawasan industri perikanan akan di kembangkan di wilayah Tiley dan sekitarnya, diaman wilayah ini juga ditetapkan sebagai kawasan strategis kabupaten dalam bentuk KEK (Kawasan Ekonomi Khusus).

Pariwisata; sesuai dengan potensi bahari dan keindahan alamnya pariwisata merupakan salah satu andalan sebagai lokomotif pertumbuhan ekonomi wilayah. Pada sisi lain, pariwisata akan mendorong pembangunan wilayah yang lebih mengedepankan kaidah-kaidah perencanaan, arsitektural, budaya lokal, estetika dan kualitas lingkungan. Kawasan ini, antara lain Pulau Dodola yang direncanakan untuk dikembangkan sebagai kawasan wisata bahari Pulau Morotai. 


\section{Potensi Ekonomi Pariwisata Kabupaten Pulau Morotai}

Wisatawan melakukan perjalanan wisata karena adanya dorongan daya tarik dari destinasi wisata serta biaya perjalanan yang sangat mempengaruhi tingginya permintaan untuk melakukan perjalanan. Biaya perjalanan bisa bersifat absolut dan relatif (Marpaung dan Bahar, 2002). Menurut Banapon (2008) daya dukung wisatawan untuk Kabupaten Pulau Morotai dengan total luas pantai $510.000 \mathrm{~m}^{2}$ adalah 20.400 orang perhari. Sedangkan jumlah kunjungan wisatawan tahun 2014 ke Kabupaten Pulau Morotai dalam setahun 891 jiwa (Dinas Pariwisata 2015 dalam Bappeda Kabupaten Pulau Morotai 2015b), masih jauh dari jumlah orang yang dapat tertampung dalam suatu kawasan wisata. Jika dilihat trend kunjungan wisatawan menurun $55,7 \%$ pada tahun 2014. Hal ini disebabkan Kabupaten Pulau Morotai jika dilihat dari segi akses cukup jauh dan fasilitas untuk mendukung pariwisata kurang memadai jika dibandingkan dengan destinasi wisata di Maluku Utara yang sudah lebih dahulu terkenal.

Berdasarkan hasil wawancara dan observasi penyebab menurunnya jumlah kunjungan wisatawan karena rendahnya promosi dan membidik wisatawan negara tertentu sepertinya halnya membidik wisatawan dari Jepang yang memiliki konektivitas sejarah dengan Morotai dalam hubungan sejarah Perang Dunia II. Kunjungan wisatawan ke Kabupaten Pulau Morotai mulai menurun setelah tahun 2012 (Gambar 1). Hal ini diduga karena tingginya kunjungan pada tahun 2012 bersamaan dengan berlangsungnya event Sail Morotai. Kemungkinan besar wisatawan yang sudah pernah berkunjung ke Kabupaten Pulau Morotai tidak berkunjung kembali disebabkan fasilitas yang kurang memadai dan akses yang cukup jauh. Hal senada juga disampaikan oleh Naude dan Saayman (2005) yang menyebutkan bahwa infrastruktur sebagai salah satu faktor penentu seorang wisatawan untuk berkunjung kembali selain kondisi politik, biaya perjalanan dan isu kesehatan. Berdasarkan hasil wawancara dengan pengelola Daloha Resort, tamu hotel berasal dari wisatawan domestik dan luar negeri. Wisatawan luar negeri sebagian besar berasal dari negara Jepang, kemudian diikuti oleh wisatawan dari Cina, Australia, Belanda. Singapura, Malaysia, Taiwan. Jerman, New Zealand, Belgia. Menurut Bappenas (2016), berdasarkan rataan jumlah hari tinggal di Indonesia biasanya dilakukan oleh wisatawan dari Eropa, Amerika Utara, Tengah dan Latin kurang lebih 13 hari lebih tinggi jika dibandingkan wisatawan Asia dan Timur Tengah yang menghabiskan liburan di Indonesia kurang lebih 7 hari. Namun berbanding terbalik wisatawan Asia dan Timur Tengah yang cenderung mengeluarkan biaya harian sebesar US\$136,14 lebih tinggi dari pengeluaran wisatawan Eropa, Amerika Utara, Tengah dan Latin sebesar US\$ 111,38. Rataan pengeluaran wisatawan asing tanpa melihat asal negara adalah sebesar US\$123,50 senada dengan rata-rata pengeluaran wisatawan yang menggunakan operator diving lebih dari US\$ 100 perhari yang digunakan untuk akomodasi, konsumsi, transportasi lokal di Kabupaten Pulau

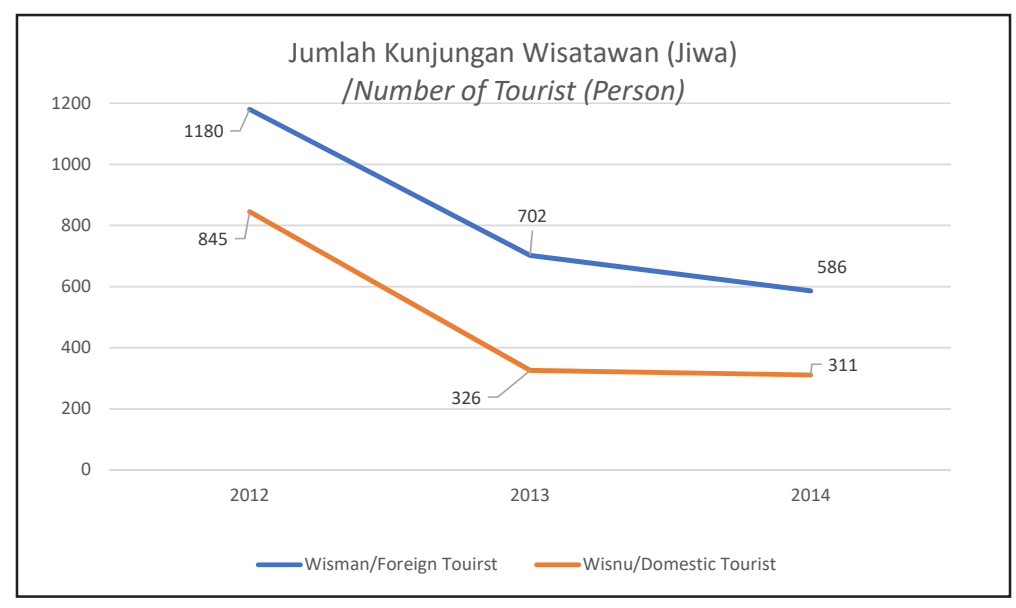

Gambar 1. Jumlah Kunjungan Wisatawan Mancanegara dan Wisatawan Domestik di Kabupaten Pulau Morotai dari Tahun 2012-2014.

Figure 1. Numbers of Foreign and Domestic Tourist in Morotai Island Regency From 2012-2014.

Sumber: Dinas Pariwisata Kabupaten Pulau Morotai 2015 dalam Bappeda Kabupaten Pulau Morotai 2015b)/

Source: Tourism Agency of Morotai Island Regency 2015 in Development Planning Agency of Morotai Island Regency 2015b) 
Morotai (Shark Diving Indonesia, 2014). Jika ditotal biaya perjalanan wisatawan asing untuk melakukan perjalanan wisata lebih besar dari $200 \%$ dibandingkan dengan wisatawan domestik. Dari hasil penelitian Brida et al. (2010b) menunjukkan wisatawan asing memberikan dampak positif terhadap pertumbuhan ekonomi Trentino-Alto Adige sebagai destinasi wisata. Dampak positif itu berasal dari biaya yang dikeluarkan oleh wisatawan asing selama melakukan perjalanan wisata.

Berdasarkan hasil penelitian Banapon (2008) adapun jenis biaya yang dikeluarkan, antara lain biaya transportasi, konsumsi, akomodasi, belanja souvenir dan biaya lainnya. Dengan memperhatikan inflasi Kabupaten Pulau Morotai nilai pariwisata yang diperoleh dari pendekatan Travel Cost Method (TCM) dan Willingness To Pay (WTP) adalah sebesar Rp11.603.275.657. Surplus konsumen perindividu tahun 2006 yang diperoleh dari perhitungan TCM sebesar Rp. 1765,6 kemudian menggunakan discount rate sebesar $6,15 \%$ untuk memperoleh surplus konsumen perindividu tahun 2014 sebesar Rp 2.934 yang kemudian dikalikan dengan jumlah wisatawan yang berkunjung ke Kabupaten Pulau Morotai tahun 2014 tercatat sebanyak 897 orang sehingga diperoleh nilai pariwisata Kabupaten Pulau Morotai sebesar Rp2.631.543.Dengan pendekatan WTP diperoleh nilai pariwisata Kabupaten Pulau Morotai tahun 2014 sebesar Rp11.600.644.114,-yang diperoleh dari perhitungan WTP per individu setelah menghitung discount rate yaitu sebesar Rp12.932.714. Jika dijumlahkan maka total nilai pariwisata Kabupaten Pulau Morotai dengan menggunakan hasil penelitian Banapon (2008) sebesar Rp11.603.275.657,-. Untuk lebih jelas tertuang dalam Tabel 2.
Nilai ini lebih rendah dengan hasil perhitungan menggunakan pendekatan estimasi pengeluaran wisatawan yang diperoleh dari berbagai sumber baik hasil penelitian sejenis yang telah dilakukan sebelumnya, promosi paket wisata Morotai serta laporan dari dinas terkait. Nilai pariwisata diperoleh dari total pengeluaran pertrip wisatawan domestik dan wisatawan mancanegara. Pengeluaran wisatawan domestik dan wisatawan mancanegara berbeda karena jumlah hari berkunjung berbeda. Wisatawan domestik rata-rata menghabiskan waktu berkunjung selama 4 hari 3 malam sedangkan wisatawan mancanegara rata-rata menghabiskan waktu berkunjung selama 11 hari 10 malam (BPS,2016). Perbedaan waktu berkunjung sangat mempengaruhi besaran transaksi ekonomi pada saat melakukan kegiatan wisata. Besaran transaksi ekonomi yang dilakukan oleh wisatawan domestik sebesar Rp5.305.000/trip dan dikalikan dengan jumlah wisatawan domestik tahun 2014 sebanyak 311 orang, maka diperoleh nilai pariwisata yang disumbang dari wisatawan domestik sebesar Rp1.649.855.000,- sedangkan besaran transaksi ekonomi yang dilakukan oleh wisatawan mancanegara sebesar Rp19.872.500/ trip dan dikalikan dengan jumlah wisatawan mancanegara tahun 2014 sebanyak 586 orang, maka diperoleh nilai pariwisata yang disumbang dari wisatawan mancanegara sebesar Rp11.645.285.000. Total nilai pariwisata Kabupaten Pulau Morotai adalah Rp13.295.140.000,-. Jika potensi ekonomi pariwisata Kabupaten Pulau Morotai jika ditarik pada tahun 2017 dengan discount rate 5,96\% maka terhitung potensi ekonomi pariwisata adalah Rp. 15.986.561.161,-. Untuk lebih jelas tertuang dalam Tabel 3.

Tabel 2. Nilai Ekonomi Pariwisata Kabupaten Pulau Morotai dengan Pendekatan Discounting. Table 2. Tourism Economic Value of Morotai Island Regency With Discounting Approach.

\begin{tabular}{lcr}
\multicolumn{1}{c}{ Jenis/Type } & $\mathbf{2 0 0 6}$ & \multicolumn{1}{c}{$\mathbf{2 0 1 4}^{1}$} \\
\hline Surplus Konsumen Individu/Individual Consumer Surplus & 1,766 & 2,934 \\
Total Surplus Konsumen/Total Consumer Surplus & & $2,631,543$ \\
Kemampuan Membayar Individu/Individual Willingness to pay & $7,783,302$ & $12,932,714$ \\
Total Kemampuan Membayar/Total Willingnes to pay & & $11,600,644,114$ \\
Total Nilai Ekonomi Pariwisata/Total Tourism Economic Value & & $11,603,275,657$ \\
\hline
\end{tabular}

Keterangan/Remaks

${ }^{1}$ Nilai diperoleh dengan melakukan discounting dengan discount rate: 6,15\%/

${ }^{1}$ Value is obtained by discounting with a discount rate: $6.15 \%$

${ }^{2}$ Jumlah wisatawan tahun 2014 sebanyak 897 orang/ ${ }^{2}$ The number of tourists in 2014 was 897 people 
Tabel 3. Nilai Ekonomi Pariwisata Kabupaten Pulau Morotai dengan Pendekatan Biaya Perjalanan Wisata Wisatawan Domestik dan Wisatawan Mancanegara Pertrip.

Table 3. Tourism Economic Value of Morotai Island Regency With Total Expenditure of Domestic Tourist and Foreign Tourist pertrip.

\begin{tabular}{lcc}
\hline \multicolumn{1}{c}{ Jenis/Type } & $\mathbf{2 0 1 4}$ & $\mathbf{2 0 1 7}$ \\
\hline $\begin{array}{l}\text { Biaya Perjalanan Wisatawan Domestik/ } \\
\text { Travel Cost of Domestic Tourist }\end{array}$ & $1,649,855,000$ & $1,983,845,816$ \\
$\begin{array}{l}\text { Biaya Perjalanan Wisatawan Mancanegara/ } \\
\text { Travel Cost of Foreign Tourist }\end{array}$ & $11,645,285,000$ & $14,002,715,345$ \\
$\begin{array}{l}\text { Total Nilai Ekonomi Pariwisata/ } \\
\text { Total Tourism Economic Value }\end{array}$ & $13,295,140,000$ & $15,986,561,161$ \\
\hline
\end{tabular}

Keterangan/Remaks

${ }^{1}$ Nilai diperoleh dengan melakukan discounting dengan discount rate: $5,96 \%$ /

${ }^{1}$ Value is obtained by discounting with a discount rate: $5,96 \%$

Jika membandingkan nilai potensi ekonomi pariwisata di berbagai destinasi wisata yang telah ditetapkan oleh pemerintah sebagai destinasi utama wisata Indonesia seperti Menjangan Bali, Kepulauan Seribu DKI Jakarta dan Gili Matra NTB, Kabupaten Pulau Morotai memiliki nilai potensi ekonomi yang jauh di bawah destinasi tersebut. Hal ini menunjukkan bahwa pembangunan pariwisata tiga destinasi tersebut sudah ada sejak tahun 1990an dan dari segi akses sangat mudah karena sudah terhubungan dengan moda transportasi udara yang memiliki jadwal penerbangan lebih dari 5 kali dalam seminggu. Nilai ekonomi potensi Pariwisata Kabupaten Pulau Morotai yang dilakukan oleh Banapon (2008) terhitung sebesar Rp46.708.856,- serupa dengan nilai ekonomi potensi pariwisata Karimunjawa tertuang dalam penelitian yang dilakukan oleh Anggraeni (2009) sebesar Rp77.536.080,-. Hal ini dikarenakan kondisi pariwisata Karimunjawa dibawah tahun 2010 belum berkembang pesat seperti 4 tahun terakhir. Hal ini dikarenakan akses menuju Karimunjawa tidak semudah sekarang dengan jumlah penyeberangan dalam seminggu lebih dari 13 kali dari Pantai Kartini Jepara dan belum termasuk akses via udara dengan menggunakan pesawat perintis. Kondisi pariwisata Karimunjawa di bawah tahun 2010 hampir sama dengan kondisi pariwisata Kabupaten Pulau Morotai dengan jumlah kunjungan wisatawan dibawah 2000 orang dalam setahun dan akses yang terjangkau secara terbatas. Sangat berbeda dengan nilai ekonomi Karimunjawa pada tahun 2012 yang signifikan nilai ekonomi meningkat terlihat dari jumlah wisatawan yang berkunjung meningkat 6 kali lipat. Untuk lebih detail perbandingan nilai ekonomi pariwisata dari berbagai hasil penelitian tertuang dalam Tabel 4.

Tabel 4. Nilai Ekonomi Pariwisata dari Berbagai Hasil Penelitian. Table 4. Economic Tourism Value of Various Research Results.

\begin{tabular}{|c|c|c|c|c|c|c|c|c|}
\hline No & $\begin{array}{l}\text { Lokasi// } \\
\text { Location }\end{array}$ & $\begin{array}{c}\text { Tahun } \\
\text { Penelitian/ } \\
\text { Research } \\
\text { Year }\end{array}$ & $\begin{array}{l}\text { Pendekatan/ } \\
\text { Research } \\
\text { Approach }\end{array}$ & $\begin{array}{c}\text { Surplus } \\
\text { Konsumen/ } \\
\text { WTPI } \\
\text { Consumer } \\
\text { Surplus/WTP }\end{array}$ & $\begin{array}{c}\text { Jumlah } \\
\text { Wisatawan/ } \\
\text { Number of } \\
\text { Tourist }\end{array}$ & $\begin{array}{l}\text { Nilai Ekonomi/ } \\
\text { Economic Value }\end{array}$ & $\begin{array}{c}\text { Nilai Ekonomi } \\
\text { Tahun } 2014 \text { Setelah } \\
\text { Diskon Faktor 6,15\%/ } \\
\text { Economic Value in } \\
2014 \text { with Discount } \\
\text { Factors } 6,15 \%\end{array}$ & Sumber/Source \\
\hline 1 & $\begin{array}{l}\text { Menjangan } \\
\text { Bali }\end{array}$ & 2005 & TCM & $13,077,232$ & 14,191 & $185,579,000.000$ & $3,228,392,777,914$ & Andalita, 2006. \\
\hline 2 & $\begin{array}{l}\text { Kepulauan } \\
\text { Seribu }\end{array}$ & 2009 & TCM & 937,000 & 98,050 & $97,241,142,846$ & $251,962,494,869$ & Putri. 2009. \\
\hline 3 & Karimunjawa & 2008 & CVM & 60,199 & 1,288 & $77,536,080$ & $294,024,842$ & Anggraeni, 2009. \\
\hline 4 & Gili Matra & 2006 & TCM & $5,362,536$ & 14,968 & $80,266,441,929$ & $788,678,572,000$ & $\begin{array}{l}\text { Yulianto et al., } \\
2007 .\end{array}$ \\
\hline 5 & Karimunjawa & 2012 & TCM & 550,250 & 9,054 & $4,981,963,500$ & $6,026,951,693$ & Nahib et al., 2012. \\
\hline
\end{tabular}

Sumber: Andalita, V. 2006, Putri. 2009. Anggraeni, 2009, Yulianto et al.,2007 Nahib et al., 2012. (Data diolah kembali, 2017)/

Source: Andalita, V. 2006, Putri. 2009. Anggraeni, 2009, Yulianto et al., 2007 Nahib et al., 2012. (Data Have Been Processed, 2017) 
Hasil dari multilateral meeting yang dilaksanakan oleh BAPPENAS tercatat proyeksi devisa dari kunjungan wisatawan mancanegara sebesar USD 500.000 dengan pembangunan infrastruktur untuk mendukung sektor pariwisata sebesar USD 3.600 .000 yang nantinya dapat mengakomodasi wisatawan mancanegara sebanyak 500.000 jiwa dan proyeksi devisa yang diperoleh mencapai USD 500.000.000. atau 6,75 triliun rupiah (Bappenas, 2016). Masukan lainnya dari hasil penelitian Moerwanto dan Junoasmono (2017) untuk pengembangan infrastruktur pariwisata di Kabupaten Pulau Morotai adalah menyusun Masterplan Pariwisata yang menyeluruh dan terintegrasi salah satunya menyusun program dukungan infrastruktur jalan dengan berkoordinasi dengan lembaga terkait serta mencari sumber pendanaan lain selain APBN atau APBD seperti pinjaman luar negeri. Penyusunan Masterplan Pariwisata harus memuat konsep wisata berkelanjutan yaitu strategi yang digunakan untuk mengelola aktivitas pariwisata yang fokus terhadap dampak yang ditimbulkan terhadap sumber daya alam. Masterplan Pariwisata harus memuat kebijakan pengelolaan pesisir dan laut, fasilitas lingkungan, perawatan infrastruktur, peningkatan kapasitas dan pengembangan ekonomi untuk mendukung keberlanjutan sumber daya alam (Hengky, 2017).

Pariwisata memberikan dampak positif terhadap perekonomian. Dampak yang terlihat langsung adalah adanya pembukaan lapangan kerja baru serta peningkatan devisa negara dan memberikan efek jangka panjang terhadap pertumbuhan ekonomi. Hasil penelitian yang dilakukan oleh Nizar (2011), pertumbuhan ekonomi yang tahun sebelumnya akan memberikan dampak langsung terhadap pendapatan pada 3 triwulan pertama tahun berjalan. Di Indonesia ekonomi bertumbuh dan kegiatan pariwisata memiliki hubungan kausalitas timbal balik yaitu saling memberikan manfaat satu dengan yang lain.

\section{KESIMPULAN DAN IMPLIKASI KEBIJAKAN}

\section{Kesimpulan}

Berdasarkan hasil dan pembahasan diatas terhitung potensi ekonomi Pariwisata Kabupaten Pulau Morotai adalah Rp.13.295.140.000 merujuk pada discount rate tahun 2014 sebesar $6.15 \%$. Nilai ini disumbang dari wisatawan domestik dan wisatawan mancanegara yang berkunjung ke Kabupaten Pulau Morotai berkisar selama 4 - 11 hari.

\section{Implikasi Kebijakan}

Dengan memasukan potensi ekonomi dalam dokumen Masterplan Pariwisata sebagai dasar besaran anggaran yang dibutuhkan dalam pengembangan pariwisata dan membuka pintu investasi dalam skema penanaman modal oleh investor. Pertumbuhan ekonomi sangat signifikan memberikan pengaruhnya terhadap peningkatan pariwisata kebijakan pengembangan pariwisata sebaiknya tidak terpisahkan dengan investasi ekonomi Kabupaten Pulau Morotai yang mendukung kegiatan pariwisata seperti hotel, bandara udara, pelabuhan, jalan raya dan pengembangan pada masing-masing daerah aktraksi wisata. Dalam penyusunan Masterplan Pariwisata mengajak keterlibatan masyarakat dalam perencanaan dan pengembangan karena dengan adanya keterlibatan masyarakat menambahkan kepentingan masyarakat untuk menjadikan pariwisata di Kabupaten Pulau Morotai berhasil.

\section{UCAPAN TERIMA KASIH}

Ucapan terima kasih diberikan kepada rekan-rekan peneliti Balai Besar Riset Sosial Ekonomi Kelautan dan Perikanan atas masukan dan sarannya untuk kesempurnaan tulisan ini. Ucapan terima kasih juga diberikan kepada Bapak John Lynham selaku pengajar workshop Economic Valuation yang diselenggarakan oleh Conservation Society Fund (CSF) Tahun 2016 dan memberikan pengajaran terkait konsep berpikir untuk membahas nilai ekonomi pariwisata dengan studi kasus pariwisata di Kepulauan Galapagos.

\section{DAFTAR PUSTAKA}

Andalita, V. 2006. Valuasi Ekonomi Ekosistem Terumbu Karang di Perairan Pulau Menjangan Provinsi Bali. (Skripsi). Program Studi Manajemen Bisnis dan Ekonomi Perikanan Kelautan Fakultas Perikanan dan IImu Kelautan Institut Pertanian Bogor.

Anggraeni, R. 2009. Valuasi Ekonomi Ekosistem Terumbu Karang Taman Nasional Karimunjawa. (Skripsi). Program Studi Manajemen Bisnis dan Ekonomi Perikanan.

Banapon, M.M. 2008. Penilaian Ekonomi Wisata Bahari di Pulau Morotai Kabupaten Halmahera Utara, Provinsi Maluku Utara. Sekolah Pascasarjana Institut Pertanian Bogor Program Studi Ekonomi 
Sumber daya Kelautan Tropika. (Tesis). 100 halaman.

Bappeda Kabupaten Pulau Morotai. 2015a. Penyusunan Revisi Rencana Tata Ruang Wilayah (RTRW) Kabupaten Pulau Morotai. Bappeda Kabupaten Pulau Morotai. 174 halaman.

. 2015b. Profil Daerah Kabupaten Pulau Morotai Tahun 2015. Bappeda Kabupaten Pulau Morotai. 68 halaman.

Bappenas. 2016. Pembangunan Pariwisata. Disampaikan dalam Multilateral Meeting Kedeputian Bidang Ekonomi. (Online). Tersedia di Laman: https://www. bappenas.go.id/files/penyusunan_rkp_2017/ seri_multilateral_meeting/Pembangunan_ Pariwisata_Update_2_Maret_2016.pdf. Diakses Pada Tanggal: 29 November 2017.

BPS. 2016. Rata-Rata Lama Tinggal Wisatawan Mancanegara Menurut Negara Tempat Tinggal, 2002-2015 (Hari). (Online). Tersedia di Laman: http://www.bps.go.id/LinkTabelStatis/view/ id/1389. Diakses pada Tanggal 29 November 2017.

BPS Kabupaten Pulau Morotai. 2018. Produk Domestik Regional Bruto Kabupaten Pulau Morotai Menurut Lapangan Usaha Tahun 2013-2017. BPS Kabupaten Pulau Morotai. 145 Halaman.

Brida, J.G., B.Lanzilotta, S. Lionetti and W.A. Risso. 2010a. Research Note: Tourism-Led Growth Hyp*othesisi For Uruguay. Tourism Economics Volum 16 Number 3. pp.765-771.

Brida, J.G, A. Barquet and W.A. Risso. 2010b. Causality Between Economic Growth and Tourism Expansion: Empirical Evidence from Trentino-Alto Adige. Tourismo: An International Multidisciplinary Journal of Tourism Volume 5 Number 2 Autumn 2010. Pp. 87-98.

Ditjen Imigrasi dan BPS. 2017. Laporan Bulanan Desember 2017 (Angka Revisi): Perkembangan Kunjungan Wisman Ke Indonesia Tahun 2017 vs 2016. (Online). Tersedia di Laman: http://www. kemenpar.go.id/userfiles/12_\%20Lapbul\%20 Des\%202017\%20(Angka\%20Revisi).pdf. Diakses Pada Tanggal: 15 April 2018.

Fauzi, A. 2004. Ekonomi Sumberdaya Alam dan Lingkungan. PT. Gramedia Pustaka Utama Jakarta.

Fauzi, A. 2014. Valuasi Ekonomi dan Penilaian Kerusakan Sumber Daya Alam dan Lingkungan. IPB Press. Bogor. 246 Halaman.

Harahap, N. 2014. Penelitian Kepustakaan. Jurnal Iqra' Volume 8 Nomor 1 Mei 2014. Halaman 68-73.

Hengky, S.H. 2017. Discovering Sustainable Coastal Tourism in Dodola Island Indonesia. J Aquac Mar Biol 6 (2): 00152. DOI: 10.15406/ ja.2017.06.00152. 8 Halaman.
Kementerian Pariwisata. 2015. Rata-Rata Pengeluaran Wisman PerHari Menurut Tempat Tinggal 2009-2014. (Online). Tersedia di Laman:http:// www.kemenpar.go.id/userfiles/RATA\%20-\%20 RATA $\% 20$ PENGELUARAN $\% 20$ WISMAN $\% 20$ PER \% 20 H A R I \% 20 M E N UR U T \% 20 NEGARA\%20TEMPAT\%20TINGGAL, \% 20 2009\%20-\%202014.pdf. Diakses pada Tanggal 29 November 2017.

Kementerian Pariwisata Republik Indonesia. 2016. Rangking Devisa Pariwisata Terhadap Komoditas Ekspor Lainnya. (Online). Tersedia di Laman: http://www.kemenpar.go.id/userfiles/ devisa2011-2015.pdf Diakses pada tanggal: 13 April 2018.

Khumaedy, M.A. 2017. Tahun 2017 Kita Genjot Sektor Pariwisata. (Online). Tersedia di Laman: http:// setkab.go.id/tahun-2017-kita-genjit-sektorpariwisata/. Diakses pada tanggal: 13 April 2018.

Letson, D. 2002. Chapter 1 Economic Value and Environmental Quality Florida's Coastal Resources. Florida Coastal Environmental Resources: A Guide to Economic Valuation and Impact Analysis ISBN 0-916287-52-1. Florida Sea Grant College Program and NOAA. pp :1-6.

Marpaung, H. dan H. Bahar. 2002. Pengantar Pariwisata. Alfabeta.Bandung. 197 Halaman.

Martono, N. 2011. Metode Penelitian Kuantitatif: Analisis Isi dan Analisis Data Sekunder Edisi Revisi 2. Rajawali Pers. Jakarta. 270 Halaman

Moerwanto, A.S dan T. Junoasmono. 2017. Strategi Pembangunan Infrastruktur Wisata Terintegrasi. Jurnal HPJI Volume 3 Nomor 2 Juli 2017. Halaman 67-78.

Mulyadi, M. 2011. Penelitian Kuantitatif dan Kualitatif Serta Pemikiran Dasar Menggabungkannya. Jurnal Studi Komunikasi dan Media Volume 15 Nomor 1 Juni-Januari 2011. Halaman 127-138.

Nahib, I., Y. Suwarno dan S. Arief. 2012. Pemetaan Terumbu Karang dan Nilai Ekonomi Berdasarkan Travel Cost Method: Studi Kasus di Taman Nasional Karimunjawa. Globe Volume 14 Nomor 1 Juni 2012. Halaman 7-16.

Naude, W.A and A. Saayman. 2005. Determinats of Tourist Arrivals in Africa: a Panel Data Regression Analysis. Tourism Economics Volume 11 Nomor 3. Halaman 365-391.

Nizar, M.A. 2011. Tourism Effect on Economic Growth in Indonesia. Munich Personal RePEc Archive No 65628. (Online). Tersedia di Laman http:// mpra.ub.uni-muenchen.de/65628. Diakses Pada Tanggal 10 Maret 2018.

Purwanto. 2013. Valuasi Ekonomi Ekowisata Dengan Model Travel Cost dan Dampaknya Terhadap Usaha Kecil Pariwisata. Jurnal Manajemen dan Kewirausahaan Volume 15 Nomor 1 Maret 2013 ISSN 1411-1438. Halaman 89-102. 
Putri, I.A.N. 2009. Valuasi Ekonomi Terumbu Karang Kawasan Konservasi Laut Kepulauan Seribu. (Tesis). Sekolah Pascasarjana Institut Pertanian Bogor.

Shark Diving Indonesia. 2014. Wreck Diving. (Online). Tersedia di Laman: https://sharkdivingindonesia. com/2014/01/31/selam-morotai/. Diakses Pada Tanggal 29 November 2017.

Spillane, J.J. 1987. Ekonomi Pariwisata Sejarah dan Prospeknya. Kanisius. Yogyakarta. 150 Halaman.

Sugiyono. 2013. Metode Penelitian Manajemen. Alfabeta. Bandung. 806 Halaman.

Wirartha, I. M. 2006. Metodologi Penelitian Sosial Ekonomi. ANDI. Yogyakarta. 390 halaman.

www. indonesia-investments.com. 2016. Industri Pariwisata Indonesia. (Online). Tersedia di Laman:https://www.indonesiainvestments.com/ $\mathrm{id} /$ bisnis/industrisektor/pariwisata/item6051?. Diakses pada tanggal: 13 April 2018.

Yulianto, G., A. Fahrudin, dan N. Kusmaningsih. 2007. Analisis Permintaan Rekreasi dan Strategi Pengembangan Wisata Bahari di Gili Trawangan Kabupaten Lombok Barat Provinsi Nusa Tenggara Barat. Buletin Ekonomi Perikanan Volume VII No 2 Tahun 2007. IPB Bogor.

Zamroni, A., I. Muliawan, S.H. Suryawati, A. Ramadhan, P.A. Soejarwo, M. Firdaus, C.M. Witomo, R. Triyanti, Lindawati dan A. Elly. 2016. Laporan Teknis Penelitian Valuasi Ekonomi Sumber daya Kelautan dan Perikanan di Lokasi Rehabilitasi dan Wisata Bahari. Pusat Penelitian Sosial Ekonomi Kelautan dan Perikanan (tidak dipublikasikan).

\section{Peraturan Perundang-undangan}

Instruksi Presiden Republik Indonesia No. 7 Tahun 2016 Tentang Percepatan Pembangunan Industri Perikanan Nasional.

Peraturan Pemerintah No. 50 Tahun 2014 Tentang Kawasan Ekonomi Khusus Morotai. 